\title{
Trading Our Way out of War: Perpetual Peace
} without Politics

Comércio em vez de guerra: paz perpétua sem política

Le commerce plutôt que la guerre: paix perpétuelle sans politique

Patrícia Vieira

\section{OpenEdition}

\section{Journals}

Electronic version

URL: http://journals.openedition.org/rccs/7088

DOI: $10.4000 /$ rccs. 7088

ISSN: 2182-7435

\section{Publisher}

Centro de Estudos Sociais da Universidade de Coimbra

\section{Printed version}

Date of publication: 1 September 2018

Number of pages: 5-22

ISSN: 0254-1106

\section{Electronic reference}

Patrícia Vieira, «Trading Our Way out of War: Perpetual Peace without Politics », Revista Crítica de Ciências Sociais [Online], 116 | 2018, Online since 31 July 2018, connection on 11 September 2020 . URL : http://journals.openedition.org/rccs/7088 ; DOI : https://doi.org/10.4000/rccs.7088 


\title{
PATRÍCIA VIEIRA
}

\section{Trading Our Way out of War: Perpetual Peace without Politics}

\begin{abstract}
Proponents of perpetual peace have often identified politics as a problem standing in the way of peaceful relations between humans. They believed that, while politics exacerbates the differences separating nations, commerce brings human beings together. In this article, I trace the development of arguments against politics and for commerce from the late fifteenth to the early nineteenth century. I argue that thinkers espoused an idealized view of commerce as an activity that fostered the development of a peaceful international community, while gradually eliminating economic inequalities. I also highlight how these arguments still resonate with today's debates on globalization.
\end{abstract}

Keywords: conflicts resolution; economic relations; free trade; globalization; peacebuilding; perpetual peace; political relations.

\section{A World Mercantile Republic}

The best political path towards establishing perpetual peace amongst human beings has long been a heated subject of debate. Some have endorsed the creation of a federation of states that would mediate conflicts between its members. Initially, this alliance was imagined as including only European, Christian nations, as in the proposals of Quakers William Penn and John Bellers, or in the more famous projects of the Abbé de Saint-Pierre or Jean-Jacques Rousseau, but it could be expanded to encompass all countries of the world. Yet, how to persuade states to enter such a federation? And should it be a loose coalition of nations or a tightly knit political union, following the model later adopted by the United States of America? In his renowned essay on perpetual peace, Immanuel Kant is ambiguous about the political form of the peaceful time to come. He puts forth the idea of an international state that would embrace all human beings, but quickly recognizes that this cosmopolitan world republic (Weltrepublik) would not be feasible (Kant, 2008a: 105). Eighteenth- and nineteenth-century pacifists saw in the development of international law the safest political road to a 
lasting world peace. But who was to enforce international right? One state, a group of states, or an organization representing all nations? And whence would such an international body derive its political clout?

Given the seemingly unsurmountable difficulties surrounding the political route to perpetual peace, a possible answer to the question of abolishing war began to emerge from a different quarter. What if perpetual peace could not be achieved through political means? Could politics be the problem and not part of the solution? What if the end of history will take the shape neither of a federation of nations nor of an international state but, rather, of a "great mercantile republic", to borrow Adam Smith's formulation (Smith, 2012 [1776]: 433), where each human being strives towards her own interest and, concomitantly, the interest of all?

\section{Make Business, Not War}

Advocates for peace often identify the disruption of trade as one of the negative consequences of war. Armed conflict lays waste the land, thus diminishing the amount of agricultural products that can be traded. At the same time, it impedes commercial exchange not only between warring nations but, more broadly, in the whole region where fighting takes places, due to insecurity and to the destruction of roads, harbors, and so on. In his passionate plea against war, The New Cyneas (1909 [1623]), Émeric Crucé contrasts the destruction brought about by soldiers to the wealth that merchants generate:

[...] there is no occupation to compare in utility with that of the merchant who legitimately increases his resources by the expenditure of his labor [...]: in which he is more worthy of praise than the soldier whose advancement depends upon the spoil and the destruction of others. (Crucé, 1909 [1623]: 58)

Crucé advises princes to encourage their subjects, and especially soldiers, to turn to commerce, instead of idly waiting for the next war. For, if conflict prevents trade, the best result of a "universal peace [is] the establishment of commerce" that will bring prosperity to the nation (ibidem: 60).

The idea that trade should replace war in international relations was adroitly articulated by Jean-Baptiste Colbert in a memorandum to French King Louis XIV. "Commerce", he wrote, "is a perpetual and peaceable war of wit and energy among all nations" (apud Hont, 2010: 23). Even though he suggests that commerce is war through other means, Colbert's emphasis lies in the oxymoronically "peaceful" nature of trade wars that employ "wit and energy", instead of destructive weapons. While Colbert's policies may not always have lived up to his peaceful design, his preference for 
commerce echoed a feeling shared by a vast majority of thinkers at the time. Trade was regarded as a peaceful way to relate to other nations that softened the barbarian disposition nurtured by war. In fact, the image of commerce as a "gentle" ("doux") and innocuous activity was very widespread in Western Europe (Hirschman, 2013: 56-63). More than a century after Colbert, Jeremy Bentham was dismayed to note that politicians tended to encourage war, not trade: "All trade is in its essence advantageous - even to the party to whom it is least so. All war is in its essence ruinous; and yet the great employments of government are to treasure up occasions of war and to put fetters on trade" (Bentham, 2008: 152).

Armed conflicts are not only ruinous to a country's economy, they also deprive human beings of what is, for some thinkers, a fundamental right: the ability to trade. Spanish theologian Francisco de Vitoria, for example, saw the right to trade as an essential part of ius gentium: the law of nations or, in a more modern rendition, "international law". In his discussion of whether the native population of the Americas could be legitimately subjugated by the Spanish conquistadores, Vitoria was understandably skeptical about the legal justification for the occupation of indigenous land. Even so, he believed that "[...] the Spaniards may lawfully trade among the barbarians, so long as they do no harm to their homeland", since "travelers may carry on trade so long as they do no harm to the citizens" (Vitoria, 2010 [1538-1539]: 279). Vitoria seems here to be adapting an old argument to a colonial setting: in other words, he is urging the Spaniards to engage in commerce, not war, with the native American population.

It is worth dwelling on Vitoria's explanation of the right to trade. Following Christian theology, he argues that, in the beginning of the world, all things were held in common and "everyone was allowed to visit and travel through any land he wished". This right was not revoked with the division of property, which should allow for human beings' "free mutual intercourse with one another" (ibidem: 278). In his move from common ownership to property, though, Vitoria seamlessly performs a conceptual leap that will be central for his defense of trade: at first he mentions only the right to travel, as trade was unnecessary in a situation when everything belonged to everyone; once property was established, the right to trade was added to the right to visit foreign regions. Vitoria sees trading rights as a pale shadow of the time when the whole world was held in common. Free commercial exchanges between human beings might restore a balance that was lost with the transformation of the world's resources into private property. Through trade, each party gets what it needs and sells its excess merchandize: "they [the indigenous population] may import the commodities which 
they lack, and export the gold, silver, or other things which they have in abundance" (ibidem). As we shall see below, the idea that trade tends toward an economic equilibrium between the various participants in a commercial exchange and, therefore, promotes the peaceful coexistence of the parties involved, will enjoy a long life in economic thought.

Vitoria was not alone in linking the right to trade to the primordial common ownership of the world by humans. In fact, this argument became a staple in the writings of natural law theorists and political philosophers alike, from Hugo Grotius, through John Locke, to Immanuel Kant. The cosmopolitanism envisioned by Kant originated in the "right to the earth's surface which the human race shares in common" (Kant, 2008a: 106). This "community of the land" that encompasses all nations is a "community of reciprocal action (commercium)", and "[e]ach [member] may offer to have commerce with the rest, and they all have a right to make such overtures" (Kant, 2008b: 172). Granted, the German word Kant used for "commerce" (Verkehr) does not exclusively mean the buying and selling of goods and services, but he certainly saw trade as a part of a larger "commerce" between all human beings. This exchange "affords the prospect that all nations may unite for the purpose of creating certain universal laws to regulate the intercourse they may have with one another" (ibidem). Kant goes even further than his predecessors, in that he squarely identifies the right to commerce with cosmopolitan right: "this right [to have commerce with others] may be termed cosmopolitan (ius cosmopolitikum)" (ibidem). The cosmopolitan world of perpetual peace envisioned by the German philosopher would be a society of traders.

The "spirit of commerce", writes Kant, "sooner or later takes hold of every people" and, because "it cannot exist side by side with war", it will lead nations towards peace (Kant, 2008a: 114). This formulation is indicative of a subtle inversion in the relationship between peace and trade that took place in post-Renaissance Europe. While, at first, most thinkers focused on the negative effects of war for commerce and, conversely, on the economic advantages of peace, the emphasis progressively shifted to trade. From being a welcome outcome of peaceful relations between states, trade became the engine that would promote cordial interactions between humans. To be sure, Kant's version of perpetual peace still entailed a strong political and legal component. However, as the idea of free trade gained momentum in economic thought, politics was increasingly regarded with suspicion. If commerce brought people together, political rivalries divided nations and often led to war. But how to do away with politics altogether? And what about the commercial wars that were becoming increasingly common in a Europe dominated by colonial powers? 


\section{Politics against Economics}

In a short 1758 essay titled "Of the Jealousy of Trade", David Hume bemoans the shortsightedness of states that look upon their neighbors as trading foes (Hume, 1987b [1758]). They mistakenly assume that, if the economy of other nations flounders, they necessarily stand to gain. Hume's not so hidden agenda here is to take a jab at mercantilist economic policies that favored the accumulation of monetary reserves and a positive balance of trade and, therefore, fostered not only economic competition but also outright political enmity between states. His portrayal of divergent positions vis-à-vis the benefits of free trade resonates with discussions on commerce that have lasted until today.

In his in-depth study of jealousy of trade, Istvan Hont outlines the debate over this issue in the seventeenth and eighteenth centuries. For Hont, the issue came to the foreground of political thought at a time when a nation's success in international commerce could determine its economic and even political survival. This politicization of commerce was perspicuously noted by Hume, who pointed out in his 1742 essay "Of Civil Liberty" that "[t]rade was never deemed an affair of state till the last century; and there scarcely is any ancient writer on politics, who has made mention of it" (Hume, 1987a [1742]). Even though Hume may have overstated his point about ancient writers' almost complete avoidance of commercial matters, he clearly identified a qualitative change in the political role played by commerce. Thinkers of the time adduced different reasons to explain the escalating jealousy of trade witnessed by Hume. Inheritors of Italian-style political republicanism saw it as a degradation of republican morality and a source of false reason of state, while natural law theorists and political economists considered it to be an anachronistic remnant of Renaissance bellicosity contaminating modern commercial societies (Hont, 2010: 10-11). In spite of widespread condemnation, jealousy of trade did not decrease, and the Seven Years' War was a painful reminder of its devastating effects. Could this problem be avoided? Would commerce fulfill its promise of bringing peace and prosperity to Europe?

The conflation of politics and economics and the ensuing application of reason-of-state thinking to international trade were clearly explosive. Several authors tried their hand at finding a solution to this conundrum in order to break the link between war and commercial development. One possible way out of the problem would be a return to a pre-modern mode of economic and socio-political organization. This was the answer put forth by, among others, Archbishop Fénelon, author of the immensely popular political novel Telemachus, Son of Ulysses (1699). In this Bildungsroman, 
Fénelon sketched the prototype of a good monarch, who should repudiate luxuriousness and lead a simple, unassuming life, a portrait widely interpreted as a criticism of the lavish court of Louis XIV. In his idealized state of Salente, agriculture was the priority, and the excess population of the cities was removed to work in the countryside. Even though the fine arts were cultivated, "superfluous arts, which divert the poor from the culture of the lands for the supply of real needs, and corrupt the rich by introducing among them luxury and softness" had been suppressed (Fénelon, 1994 [1699]: 296). In Salente, international trade would be kept to a minimum, since the country was able to produce all agricultural goods it needed and luxurious excesses were frowned upon.

Intimately related to Fénelon's imaginary Salente is the idea of completely closing off states to trade. If commerce spawned conflict, the way out of war would be to withdraw from international trade altogether, following the example of China. Fichte drew up one of the most detailed descriptions of this economic model in The Closed Commercial State (2012 [1800]). In his view, the belligerent competitiveness of European nations would only be overcome when each state developed an autonomous planned economy capable of securing the well-being of its citizens without the assistance of other countries. Unlike Fénelon, Fichte did not think that nations should focus primarily on agriculture, and industrial production played a central role in his closed commercial state. Still, he believed that the eradication of jealousy of trade required national self-sufficiency and the abolition of all commercial exchanges between states. Only full economic independence would eliminate existing reasons to wage war and inaugurate a time of perpetual peace.

For all his defense of trade, Adam Smith echoed in many sections of The Wealth of Nations (1776) the aversion of other economic theorists to the imbalances inherent in commercial societies, and especially in large commercial cities. He praised the cultivation of the land as a more solid source of wealth than trade since it is less dependent upon war and changes in government (Smith, 2012 [1776]: 413). He also believed "the lower ranks of people in the country [to be] really superior to those of the town", a fact "well known to every man whom either business or curiosity has led to converse much with both" (ibidem: 133). According to Smith, the natural progress of the economy should lead first to the development of the countryside and only later of cities. In many European states, however, this natural order of things was inverted, with manufacture and foreign trade influencing the main improvements in agriculture (ibidem: 376-377). Smith attributes part of the blame for this "unnatural and retrograde order" (ibidem: 377), 
whereby the industry of towns is superior to that of the countryside, to corporation laws and other regulations that enable the inhabitants of cities to raise the prices of their products unduly. His answer to the excesses of city life is to do away with protectionist measures that favor urban economies, so as to better reward farmers for their work (ibidem: 133).

The return to a predominantly agrarian, scarcely industrialized society and economic self-sufficiency, coupled with the closing off of a state to foreign trade, would require considerable political interference in the economy. In opposition to these two options, Smith considered that political intrusion in commercial matters in order to control economic development, through the creation of monopolies, the implementation of tax treaties, excessive taxation of certain goods, drawbacks, bounties, and so on, not only was nefarious to progress but also fueled imbalances - for example, between the city and the countryside, the metropolis and its colonies - that could lead to conflicts, as was the case with the American Revolutionary War. He was convinced that unimpaired trade functioned according to natural laws and would be beneficial to the vast majority of a nation's population. Even though some merchants might stand to lose with the end of governmental influence on commerce, a country as a whole would always profit from free markets. Smith called for the restoration of all branches of the economy to "that natural, healthful, and proper proportion which perfect liberty necessarily establishes, and which perfect liberty can alone preserve" (Smith, 2012 [1776]: 602).

The naturalization of free trade and the conception of market forces as benign economic agents, distorted only by "unnatural" political interference, undergird not only Smith's economic thought but also his understanding of social dynamics. When he writes that every individual is "led by an invisible hand to promote an end which was no part of his intention" (ibidem: 445), he is implicitly adhering to a theory of historical advancement whereby human beings unwittingly participate in a larger plan for humankind. Smith does not deny that there is "an end" to each person's actions but underlines the fact that, when promoting their own interests, individuals are usually unaware of the broader consequences of their deeds.

Smith's "invisible hand" has a function similar to that of nature in the Kantian philosophy of history, dating from less than two decades later. Both the "invisible hand" and nature were surrogates of divine providence that had a design for the development of humanity. While Kant clearly spells out the purpose of humankind - creating a perfect political constitution that would guarantee perpetual peace -, Smith never discloses what he thought would be the ultimate aim of the "invisible hand". Still, he hints at 
the fact that a peaceful society would be a commercial republic, where the economy follows its "natural" course and each individual is free to pursue her interests, contributing, at the same time, to the greater good.

Some of the inconsistencies in Kant's political thought result from his reliance on a plan of nature or of providence to reach humanity's full potential, while also counting on politics to achieve this goal. He was unwilling to abandon the idea of individual agency, as this would flatly contradict his moral philosophy, and could never fully reconcile political action with nature's work independent of human agency. Unlike Kant, Smith believed that political activity should be kept to a minimum since the - natural or providential - invisible hand would guide human beings in a peaceful direction. For him, jealousy of trade resulted from the selfishness of some merchants, who persuaded governments to trample upon public interest and bend the laws of the market so that it would work in their favor, as well as from political rivalries between different nations, and could only be avoided by severely curtailing governmental intrusion into economic matters.

The debate on jealousy of trade laid bare a contradiction that is inherent in most modern nations, a predicament in which we still find ourselves today: states are, for the most part, closed political entities but open commercial societies (Hont, 2010: 55). In order to overcome this discrepancy between the political and the economic realms, it would be necessary either to close off the economy or to do away with political divisions. Although few unreservedly embraced either of these two radical solutions, the economic views of most thinkers can be mapped along a continuum that stretches between these extremes.

As the eighteenth century wore on, the scales were tipping in favor of opening up the economy. F. H. Hinsley points out that, for the philosophes, genuine causes of war among humanity had all but disappeared. While there was a natural enmity between states, the relationship between human beings and societies was harmonious (Hinsley, 1963: 82). Wars, rivalry and deception, all part of the political landscape of Europe, could be abolished if free trade was allowed to flourish. Bellicosity was regarded as a sign of a bygone era, incongruous with the commercial spirit of the present. This conviction animated Benjamin Constant's The Spirit of Conquest and Usurpation, a pamphlet published in 1814 in opposition to Napoleon's military campaigns. For Constant, "[w]e have finally reached the age of commerce, an age which must necessarily replace that of war" (Constant, 2010 [1814]: 53). While fighting may have been warranted in the past, Constant vividly portrayed the drawbacks of the "spirit of conquest" for his age, where it survived as a pernicious anachronism. Only commerce, i.e., the "attempt to 
obtain by mutual agreement what one can no longer hope to obtain through violence", is consistent with modern European civilization.

Hume concludes his essay on jealousy of trade by sketching his vision of international commerce:

Nature, by giving a diversity of geniuses, climates, and soils, to different nations, has secured their mutual intercourse and commerce, as long as they all remain industrious and civilized. [...] I shall therefore venture to acknowledge, that, not only as a man, but as a BRITISH subject, I pray for the flourishing commerce of GERMANY, SPAIN, ITALY, and even FRANCE itself. I am at least certain, that GREAT BRITAIN, and all those nations, would flourish more, did their sovereigns and ministers adopt such enlarged and benevolent sentiments towards each other. (Hume, 1987b [1758])

The characteristics of each country make it excel at producing different merchandizes that can subsequently be exchanged for what it lacks. Trade renders states mutually dependent since "the encrease [ sic] of riches and commerce in any one nation, instead of hurting, commonly promotes the riches and commerce of all its neighbours" (Hume, 1987b [1758]). For Hume, the blindness of "sovereigns and ministers" is guilty of sowing discord and poisoning the otherwise peaceful relations between nations. But if commerce is advantageous for all and if politics is an impediment to fruitful and peaceful commercial exchanges, the very division of human beings into states becomes obsolete. Hume is already pointing towards a post-national trading community, when he writes not only as a British subject but also "as a man". For Hume, as for Smith, a future of perpetual peace would entail recognizing that, beyond political divisions, human beings are, first and foremost, trading partners in the context of the ongoing economic progress of humankind.

\section{Homo Economicus}

The understanding of commerce as a human right and the call of a variety of thinkers for a community of individuals freed from the fetters of narrow-minded political allegiances and brought together by commercial exchanges presupposed that trade is a fundamental element of human nature. Whereas, in light of Aristotle's famous definition, humans were regarded throughout most of the history of Western thought as "political animals", the rise of international commerce gave birth to a conception of humankind as primarily determined by trade.

Both Aristotle and later theorists of the economy agreed that humans were gregarious beings who came together out of necessity. They derived their 
humanity from their union; in other words, before forming social bonds, humans were not really fully human. For Aristotle, society could not be conceived of outside the polis, "which is prior in nature to the household and to each of us individually" (Aristotle, trans. 1967: 1.1253a). Only within a political system can humanity reach its full potential. This was still, mutatis mutandis, Hobbes's view of humankind: the social contract that protected individuals from the permanent war raging in the state of nature was what allowed human beings to thrive. In contrast, thinkers such as Adam Smith postulated the existence of a commercial sociability that preceded political relations and was independent from political institutions.

The commercial sociability envisioned by Smith followed in the wake of Christian notions of community. For Christian thinkers, individuals were naturally sociable and selfless, and while the Fall might have turned some away from this path, human predisposition toward cooperation could be restored through faith. Francis Hutcheson, a Christian philosopher and Smith's professor at the University of Glasgow, was a well-known critic of Hobbes's theory of the violent state of nature and a believer in an innate moral sense shared by all human beings that brought them together to create society. Smith agreed with Hutcheson's claim that humans are sociable but refused the moralizing overtones of his thought. Moving beyond his earlier moral formulations as laid out in The Theory of Moral Sentiments, Smith portrayed human sociability in The Wealth of Nations as primarily the result of self-love that drove individuals to pursue their interests and, therefore, to join with others who could help them achieve their goals. ${ }^{1}$ Smith's ideas echo the reflections on sociability by other Christian intellectuals, such as French theologian Pierre Nicole (1625-1695), who also defined civility as a product of self-love. For Nicole, it is natural to love oneself and to wish that what we love is, in turn, loved by others: we are civil, so that others love us. Human civility, then, "is only a sort of commerce of self-love, in which one endeavors to arouse the love of others by displaying some affection towards them" (Nicole, 2003:59; emphasis added). Self-love comes naturally to humans and it is the engine that drives all other social relations.

Smith's twist to Christian doctrines of natural sociability is to stress the commercial component of sociality. In his view, people came together from early on to exchange goods, as there is "a certain propensity in human nature to truck, barter, and exchange one thing for another". It is a matter

\footnotetext{
${ }^{1}$ For a detailed analysis of the influence on Smith of theories of sociability, especially of Pufendorf, see Hont (2010), "The Language of Sociability and Commerce: Samuel Pufendorf and the Theoretical Foundations of the 'Four Stages' Theory", Jealousy of Trade. International Competition and the Nation-State in Historical Perspective, 159-184.
} 
of indifference whether this propensity is innate or arose as a consequence of the development of human rationality and language. What matters is that it "is common to all men, and to be found in no other race of animals" (Smith, 2012 [1776]: 18). As Smith makes clear in an oft-quoted passage, humans join in society with others out of self-interest, not out of moral imperatives or charitable impulses:

It is not from the benevolence of the butcher, the brewer, or the baker, that we expect our dinner, but from their regard to their own interest. We address ourselves, not to their humanity but to their self-love, and never talk to them of our own necessities, but of their advantages. (ibidem: 19)

Smith's concept of individuals as driven to sociality by self-interest and the need to exchange goods, impacts the very ontology of human beings. In modern nations "[e]very man thus lives by exchanging, or becomes in some measure a merchant, and the society itself grows to be what is properly a commercial society" (ibidem: 27). All humans have become merchants, i.e., we are all, first and foremost, economic animals that depend on trade for survival. Politics turns into little more than an accessory to the sphere of commerce:

A merchant, it has been said very properly, is not necessarily the citizen of any particular country. It is in a great measure indifferent to him from what place he carries on his trade; and a very trifling disgust will make him remove his capital, and together with it, all the industry which it supports, from one country to another. (ibidem: 413)

A merchant - and we are all merchants - does not pledge allegiance to any specific state but follows her own interests and settles where conditions for trade are more advantageous. The growth of economic migration over the past few decades, often motivated by conditions of extreme poverty in the migrants' home countries, is the darker side of Smith's vision of humans as merchants. Nonetheless, for Smith, national politics will progressively recede into the background as the world commercial republic, predicated on free trade and populated by merchants, opens up limitless possibilities for economic improvement.

In light of Smith's vision of homo economicus, it is easy to understand how peace could be achieved through trade. According to this perspective, wars were motivated by the misguided assumption that humans require a well-defined political framework and national allegiances to prosper. If pushed to its logical conclusion, Smith's conception of individuals as merchants 
would mean that politics would give way to a cosmopolitan republic of commerce. The engagement in trade would simply correspond to the unfolding of human ontology and to the fulfillment of humankind's true nature. Perpetual peace would follow from unending economic progress achieved through the ceaseless exchange of goods in an apolitical society.

\section{Commerce and Economic Equality}

A powerful, pragmatic argument bolstering the understanding of free trade as the surest path towards peace was that commercial exchanges generated prosperity and economic equality. Already Crucé had noted that when merchants are allowed to freely engage in commerce the general public stands to gain, as goods become cheaper (Crucé, 1909 [1623]: 60). More than a century and a half later, Smith would employ the same line of reasoning in his defense of free trade: when there are no impediments to free commercial exchanges, goods are made available at the cheapest possible price that still guarantees a reasonable profit to merchants. Monopolies and other interferences in the natural course of economic development might "promote the little interest of one little order of men in one country", but they will "hurt the interests of all other orders of men in that country, and of all men in all other countries" (Smith, 2012 [1776]: 609).

Free commerce is a win-win activity, and therefore contrasts starkly with war, which brings chaos and destruction even to the victors. As Hume noted, jealousy of trade was based upon a misconception about economic operations, since those who espoused it did not realize that all parties involved in commercial exchanges stand to profit. Smith expanded on this insight in The Wealth of Nations:

Between whatever places foreign trade is carried on, they all of them derive two distinct benefits from it. It carries out that surplus part of the produce of their land and labour for which there is no demand among them, and brings back in return for it something else for which there is a demand. (ibidem: 437)

Clearly, the profits of all of those involved in commerce are not the same, but Smith is adamant "that trade which, without force or constraint, is naturally and regularly carried on between any two places, is always advantageous, though not always equally so, to both" (ibidem: 479).

David Ricardo reiterated Smith's assertions on the inherently advantageous nature of trade in The Principles of Political Economy (1817). As he succinctly put it: "all trade, whether foreign or domestic, is beneficial" (Ricardo, 2004 [1817]: 214). For Ricardo, it is conceivable that one nation 
might be able to produce all goods better and more efficiently and therefore have an absolute advantage over all others. Even so, trading in some goods would still be favorable to that country, since it will allow its capital to focus on the commodities it can produce more cheaply, i.e., with comparative advantage. Hence the conclusion that

$[u]$ nder a system of perfectly free commerce, each country naturally devotes its capital and labour to such employments as are most beneficial to each. This pursuit of individual advantage is admirably connected with the universal good of the whole. [...] it diffuses general benefit, and binds together by one common tie of interest and intercourse, the universal society of nations throughout the civilized world. (ibidem: 81)

Underlying Hume, Smith and Ricardo's belief in the beneficial outcome of free trade is the notion that commerce corrects potential imbalances. It allows individuals to direct their efforts towards the most profitable activities by freeing them from the production of goods that could be made cheaper in other countries or regions. Furthermore, it harmonizes the distribution of commodities throughout the world, eliminating both surpluses and scarcities. Trade not only binds together "the universal society of nations throughout the world", as Ricardo eloquently wrote, but in point of fact it is the force that engenders this world society of buyers and sellers. It brings commodities to where they are needed, unceasingly working towards an imaginary point in the future when the entire human community will achieve a perfect equilibrium and everyone will possess exactly what they want and need.

Condillac had already elaborated on this optimistic view of the balancing ability of trade in his book Commerce and Government Considered in Their Mutual Relationship (1776). He envisioned a nation inhabited by a hard-working population divided into free cities that know "neither tolls, nor customs dues, nor arbitrary taxes, nor privileges, nor the police forces which hamper liberty" (Condillac, 2008 [1776]: 241). Commerce between the different areas of this nation played a key role in its economy: "it is essential that the surplus pours out without hindrance, reciprocally from the one [province] to the other, and that it supplies what is missing in the places where it spreads. It is a kind of ebb and flow where things balance" (ibidem: 241). For Condillac, commerce spreads goods more or less evenly between the various regions of his imaginary state and thus contributes to its social well-being.

But trade has yet another even more significant function: it evens out differences in wealth. Condillac was not so naïve as to claim that everyone 
would be equally well off in his fictional state. Some areas had a better location for trade or were more fertile, and some individuals worked harder than others, all of which generated differences in wealth. But one province could only get richer than its neighboring regions up to a certain point. When an area had attracted too much wealth, labor and raw materials became too expensive and, in a situation of free trade, buyers would turn to other, cheaper suppliers: "manufactures will gradually decay in the provinces that they have enriched, and where the price of labour has risen; while they will recover in the other provinces which they must make wealthier, and where the price of labour is lower". The poorer provinces will soon have reached a level of development similar to that of their neighbors and then the cycle will start anew: "This revolving motion will finish only to begin again [...]. [It] will be without drawbacks, because it will happen naturally and without violence" (Condillac, 2008 [1776]: 254).

In the process described by Condillac, free trade distributes riches like "a river that divides itself in a host of channels, to water all the lands in succession" (ibidem). He considers that when commerce is unhindered "wealth spreads naturally everywhere" (Condillac, 2008 [1776]: 242) and that this fosters a "continuous balancing of wealth and population between all the provinces" (ibidem: 253 ). While an entire country can never reach a permanent equilibrium of affluence, economic growth always tends towards equalization. It produces a pendulum-like movement of riches that keeps the level of wealth more or less constant in all regions.

The economic forces identified by Condillac applied only within the borders of an imaginary, isolated nation, but others realized their consequences on a broader scale. In his essay "Of Money" (1742) David Hume pointed out that differences in prosperity separating nations tended to be erased by a natural distribution of wealth:

There seems to be a happy concurrence of causes in human affairs, which checks the growth of trade and riches, and hinders them from being confined entirely to one people; as might naturally at first be dreaded from the advantages of an established commerce. [...] But these advantages are compensated, in some measure, by the low price of labour in every nation which has not an extensive commerce, and does not much abound in gold and silver. Manufactures, therefore gradually shift their places, leaving those countries and provinces which they have already enriched, and flying to others, whither they are allured by the cheapness of provisions and labour. (Hume, 1987c [1742])

Hume's explanation of the process through which economic disparities will progressively disappear prefigures some of the arguments of the debate 
surrounding Scotland's union with England in 1707. While some were skeptical about the economic advantages of this political move and believed that rich countries like England would always seek to exploit the resources of poorer ones and hamper rather than stimulate their development, the proponents of the union hoped that it would be economically advantageous for Scotland. For one, it would no longer have to compete with England for international markets. More importantly, however, were the relatively lower Scottish wages, which would prompt many English companies to move to the region, thus leading to rapid economic growth (Hont, 2010: 63ff).

\section{Conclusion}

If free trade cancelled out disparities of wealth, it had the potential to free humanity from economic inequality. Through commercial exchange, wealth would progressively spread to all regions of the world, since the very economic underdevelopment of the poor placed them at an advantage vis-à-vis wealthier nations. The balancing function of commerce, another manifestation of the invisible hand that works through human interests towards the greater good, holds the promise of a prosperous future for all states, once differences in riches have been reduced to a minimum. All similarly affluent, nations would no longer have reasons to wage wars and an era of enduring peace would ensue.

The current ideology of economic globalization rehashed this faith in the ability of the market to bring about universal well-being through unhampered free trade. Neoliberal thinkers such as Milton Friedman have restated classical arguments in favor of trade, highlighting the economic benefits of free trade identified by eighteenth and nineteenth-century liberal writers. In his bestseller, Capitalism and Freedom (1962), Friedman argues that the market is based upon the "voluntary co-operation of individuals", which rests on the presupposition that "both parties to an economic transaction benefit from it, provided that the transaction is bilaterally voluntary and informed" (Friedman, 2002 [1962]: 13). Competitive capitalism is the model of society that results from the "free coordination without coercion" of all economic processes (ibidem). In spite of these lofty ideals, the early liberal aspiration to reduce differences of wealth both within the borders of a single country and between different states, together with the neoliberal dream of increasing the wealth of all countries through free trade, failed to materialize.

There is yet another hitch to the rosy picture of worldwide peace and prosperity achieved through the balance of affluence. If free trade leads to the equalization of wealth, raising prosperity in poor countries and reducing 
it in already developed ones, why would rich nations wish to engage in it? Condillac's answer would have been that this economic harmonization takes place "imperceptibly" and that the riches lost are clearly outweighed by the benefits of living in a society where there are no harmful imbalances. Other economists were more pragmatic and, realizing the potential backlash against the idea of a self-cancelling economic development, argued that affluent states could retain their competitive edge through continuous innovation. By creating ever-increasing labor-saving technologies and specializing in high-quality products, developed nations could remain at the forefront of economic development. This would mean that poorer states would be continuously catching up with their richer counterparts, forever behind in the technological rat race. Or, alternatively, that lower-income countries would succumb to the economic might of the richer, who would exploit differences of wealth without contributing to the overall growth of poorer nations. Be it as it may, the promise of increasing economic equality continues to underlie contemporary apologias of free trade as the fastest and surest route to world peace.

Even though the dream of a society of free trade is more of a reality in today's "world mercantile republic" than early modern thinkers could ever have imagined, the aspirations of perpetual peace through commerce they espoused have failed to materialize. In our globalized societies, we are certainly living the dream of a world united by commerce but, like most dreams come true, it has not quite lived up to past expectations of perpetual peace.

Edited by João Paulo Moreira

\section{References}

Aristotle (1967), Politics. Cambridge, M.A.: Harvard University Press. Translation by H. Rackam.

Bellers, John (2008), “Some Reasons for an European State”, in Eşref Aksu (ed.), Early Notions of Global Governance. Selected Eighteenth-Century Proposals for 'Perpetual Peace'. Cardiff: University of Wales Press, 37-51 [orig. ed.: 1710].

Bentham, Jeremy (2008), "A Plan for an Universal and Perpetual Peace”, in Eşref Aksu (ed.), Early Notions of Global Governance. Selected Eighteenth-Century Proposals for 'Perpetual Peace'. Cardiff: University of Wales Press, 138-172 [orig. ed.: 1789]. Condillac, Étienne Bonnot de (2008), Commerce and Government Considered in Their Mutual Relationship. Indianapolis: Liberty Fund [orig. ed.: 1776]. Translation by Shelagh Eltis. 
Constant, Benjamin (2010), "The Spirit of Conquest and Usurpation and Their Relation to European Civilization”, in Biancamaria Fontana (ed.), Political Writings. Cambridge: Cambridge University Press, 43-167 [orig. ed.: 1814].

Crucé, Émeric (1909), The New Cyneas. Philadelphia: Allen, Lane and Scott [orig. ed.: 1623]. Translation by Thomas Willing Balch.

Fénelon, François de (1994), Telemachus, Son of Ulysses. Cambridge: Cambridge University Press [orig. ed.: 1699]. Translation by Patrick Riley.

Fichte, Johann Gottlieb (2012), The Closed Commercial State. New York: SUNY Press [orig. ed.: 1800]. Translation by Anthony Curtis Addler.

Friedman, Milton (2002), Capitalism and Freedom. Chicago/London: The University of Chicago Press [orig. ed.: 1962].

Hinsley, Francis Harry (1963), Power and the Pursuit of Peace. Theory and Practice in the History of Relations between States. Cambridge: Cambridge University Press.

Hirschman, Albert (2013), The Passions and the Interests: Political Arguments for Capitalism before Its Triumph. Princeton/Oxford: Princeton University Press.

Hont, Istvan (2010), Jealousy of Trade. International Competition and the Nation-State in Historical Perspective. Cambridge, M.A./London: The Belknap Press of Harvard University Press.

Hume, David (1987a), "Of Civil Liberty", in Eugene F. Miller (ed.), Essays, Moral, Political, Literary. Indianapolis: Library of Economics and Liberty [orig. ed.: 1742]. Accessed on 09.04.2014, at http://www.econlib.org/library/LFBooks/Hume/ hmMPL12.html.

Hume, David (1987b), "Of the Jealousy of Trade”, in Eugene F. Miller (ed.), Essays, Moral, Political, Literary. Indianapolis: Library of Economics and Liberty [orig. ed.: 1758]. Accessed on 09.04.2014, at http://www.econlib.org/library/LFBooks/Hume/ hmMPL29.html.

Hume, David (1987c), "Of Money”, in Eugene F. Miller (ed.), Essays, Moral, Political, Literary. Indianapolis: Library of Economics and Liberty [orig. ed.: 1742]. Accessed on 07.05.2014, at http://www.econlib.org/library/LFBooks/Hume/hmMPL26.html. Kant, Immanuel (2008a), "Perpetual Peace: A Philosophical Sketch", in H. S. Reiss (ed.), Kant: Political Writings. Cambridge: Cambridge University Press, 93-130 [1 $1^{\text {st }}$ ed.: 1970].

Kant, Immanuel (2008b), "The Metaphysics of Morals”, in H. S. Reiss (ed.), Kant: Political Writings. Cambridge: Cambridge University Press, 131-175 [1 $1^{\text {st }}$ ed.: 1970]. Nicole, Pierre (2003), "Moral Essays”, in Henry C. Clark (ed.), Commerce, Culture and Liberty. Readings on Capitalism before Adam Smith. Indianapolis: Liberty Fund, 54-65.

Ricardo, David (2004), The Principles of Political Economy and Taxation. Mineola, N.Y.: Dover Publications [orig. ed.: 1817].

Smith, Adam (2012), An Inquiry into the Nature and Causes of the Wealth of Nations. Ware, England: Wordsworth Editions [orig. ed.: 1776]. 
Vitoria, Francisco de (2010), “On the American Indians”, in Anthony Pagden; Jeremy Lawrance (eds.), Vitoria: Political Writings. Cambridge: Cambridge University Press, 231-292 [orig. ed.: 1538-1539].

Received on 21.10.2016

Accepted for publication on 07.05.2018

\section{Patrícia Vieira}

Centro de Estudos Sociais da Universidade de Coimbra

Colégio de S. Jerónimo, Largo D. Dinis, Apartado 3087, 3000-995 Coimbra, Portugal

Contact: pilmvieira@gmail.com

\section{Comércio em vez de guerra: paz perpétua sem política}

Os defensores da ideia de paz perpétua veem frequentemente a política como um impedimento para estabelecer relações pacíficas entre todos os seres humanos. Para eles, a política exacerba as diferenças que separam as nações, enquanto que o comércio une os seres humanos. Neste artigo, examina-se o desenvolvimento de argumentos contra a política e a favor do comércio desde finais do século XV até ao início do século XIX. Demonstra-se como muitos pensadores adotaram uma visão idealizada do comércio enquanto atividade que leva à criação de uma comunidade internacional pacífica, eliminando gradualmente desigualdades económicas. Salienta-se ainda como estas questões ecoam nos debates contemporâneos sobre globalização.

Palavras-chave: comércio livre; construção da paz; globalização; paz perpétua; relações económicas; relações políticas; resolução de conflitos.

\section{Le commerce plutôt que la guerre: paix perpétuelle sans politique}

Les défenseurs de l'idée de la paix perpétuelle voient fréquemment la politique comme un empêchement à ce que s'établissent des relations pacifiques entre tous les êtres humains. Pour eux, la politique exacerbe les différences qui séparent les nations, alors que le commerce établit des liens entre les êtres humains. Dans cet article, nous nous penchons sur le développement d'arguments contre la politique et favorables au commerce depuis la fin du Xve siècle jusqu'au début du XIXe siècle. Il y est démontré comment nombre de penseurs adoptèrent une vision idéalisée du commerce en tant qu'activité menant à la création d'une communauté internationale pacifique et éliminant graduellement les inégalités économiques. Nous y soulignons aussi combien ces questions résonnent encore dans les débats contemporains sur la globalisation.

Mots-clés: construction de la paix; globalisation; libre-échange; paix perpétuelle; relations économiques; relations politiques; résolution de conflits. 